DOI https://doi.org/10.18551/rjoas.2018-08.05

\title{
IDENTITY CONGRUENCE AS MEETING-POINT OF BETWEEN EXPECTATION- CONFIRMATION, SOCIAL IDENTITY, SOCIAL EXCHANGE AND PLANNED BEHAVIOR THEORIES TO EXPLAIN ISLAMIC CONTRIBUTION INTENTION: A CASE STUDY AT SHARIA BANKS IN LAHAT, PALEMBANG OF INDONESIA
}

\author{
Yusuf $M$. \\ Business Administration Department, State Polytechnic of Sriwijaya, Indonesia \\ Hanafi Agustina \\ Faculty of Economics, University of Sriwijaya, Indonesia \\ *E-mail: habib yosefa9@yahoo.com
}

\begin{abstract}
The study has three purposes. First, it intends to delineate constructs forming satisfaction in Islam perspective with formative approach. Second, it brings up new construct that is intention to give the best contribution. It applies SEM-PLS for data analysis. It provides several insights that enrich management literature. For one, it is among few that explores constructs forming Islamic satisfaction. The other, it is the first study that brings up new construct drawn on Islamic teaching that is intention to give best contribution which in Islam is called Shodaqoh and coined as Islamic contribution. The results are conceived to be that all predicted relationships are accepted. It has several novelties that might enrich management literature. Firstly, it is among the first that sheds light on identity congruence as a meeting point between social identity, social exchange, expectation-confirmation and planned behavior to explain an Islamic contribution intention. Secondly, it is the first research that analyzes relationship between Islamic satisfaction and an Islamic contribution. Thirdly, it is the first research that puts forward the concept of Islamic contribution intention.
\end{abstract}

\section{KEY WORDS}

Islamic contribution intention, Islamic satisfaction, Islamic culture, identity congruence.

Definition of work satisfaction within Islamic perspective refers to employees' grateful feeling that engenders blissfulness due to chance to materialize the faith and piety to God in job environment. They are allowed to do so starting from time before, during, and after completing the job (Hayaati, 2010, Saadiah, 2008). It is highly valued as work in Islam is also prayer to the God. Intention of doing job might be directed as a prayer to God, which sets the activity to reflect religious values, its performance to deliver good values or advantages to other, to make good exemplars, to make a living from decent income. Activities during the job are also treated as the way to pray to God in which one can express his/her faith, obedience, praise and contribute something to the life. The outcomes of the work are expected to deliver good results with capacity to make the world a better place to live in. Islamic satisfaction might comprises of four dimensions based on the work of Mohamad et al (2014) following AlGhazali's interpretation of Quran. They include spiritual, intellectual, social, and material dimensions.

Spiritual dimension concerns with lively heart that serve as a guidance for any attitude and behavior. It is only possible for those who have faith and base all their activities on it. They see a work as a way to seek closeness to God, get motivated to perform good deeds, and avoid mistakes that might make them away from God. They put heart on their work, thus set asides self-interests, and emphasize the greatest contribution to the greatest stakeholders. Staff or worker will have spiritual-dimension satisfaction in an organization that is perceived as being able to fulfill this end. Organization should be a place from where an individual might increase their faith, make their relationship to God closer, make their life more meaningful, and a place where they can make a valuable change and contribution to 
the world. In this study, the closest proxy is Islamic culture, where individual and organization interact to enrich their inside dimension. The individual inside dimension might be religiosity, faith, identity, self-esteem, and self-meaning, while organization's inside meaning may take the forms of brand, identity, strengthened positioned and differentiation.

Intellectual dimension concerns with the room an organization provides for the recognition, the development, the sharing, and the goodness one's knowledge might contribute. According to Al-Ghazali, as the knowledge of a person increases, so does his joy. $\mathrm{He}$ also stressed that a spirit with intellect and knowledge can give an implication to the behavior. By means of knowledge, man can develop civilization, progress, and revelations that set man apart from other creatures. By means of knowledge also, man can differentiate between goodness and the bad from which they might orient themselves toward the former and avoid the latter. Knowledge might serve as a guidance to lead to the right path, to resemble the God as Omni Science, and as a light to get to know more as to the God. Knowledge man possessed should be recognized and capitalized for day to day organizational operation as only by this way individual feel their presence in the organization meaningful, not to mention their relationship to organization getting much closer from which loyalty can be ascertained. Mutual and synergic relationship between an individual and organization makes their relationship enrich both individual and organization growth. In this study, the closest proxy is knowledge-sharing, where individual is willingly driven to share their knowledge to the organization and their interests.

Social dimension concerns with developed relationship to co-workers and employers. One of strong human being's needs, according to Al-Ghazali (1976), is social interaction. People converge on the need to interact to other, to group, and to unite and communicate from which social norm has a role. As social creature, human being is drawn to do so especially in order to have self-esteem, social recognition, protection and social meaning. Social interaction among people in Islam also reflects the individual faith to God. The stronger an individual faith is to God, the stronger ties he keep with other human beings. Many studies have confirmed that stronger relations between employees and employers will strengthen the intimate relationship. It would enable for comfortable work surroundings and make employees reluctant to leave the job. When an individual obtain satisfaction in his relationship with people with whom he or she is working with, he will feel comfortable with his working environment. In this study, the closest proxy is social norm that dictates one's attitude and behavior as it makes an individual conforms his attitude and behavior to the norm to ascertain social acceptance, identity, esteem and meaning.

Material dimension concerns with material fulfillment. The material element is related to physical needs that include but not limited to food and water; clothing; place to stay and security (Din etal., 1989). The fulfillment of physical needs might drive people to work hard. In this study, the closest proxy for material dimension is reward. Reward is found to be the major drivers of job satisfaction for most countries (Westover \& Taylor 2010). Management literature recognizes external and internal rewards. The scope of reward in this research only allows for external reward as it follows Mohamad et al's study (2014) based on Al-Ghazali's works (1976).

After the delineation of constructs forming satisfaction in Islam perspective, the study intends to explore the effect of satisfaction to Islamic contribution intention. It is important as there is a teaching concerning the significance of giving something beneficial to the interest of others which is in Islam religion is called Shodaqoh. Moslems are taught to live the life meaningfully to others. Moslem should avoid pointless activities as wasting the valuable time is considered as a sin. In this way, Moslems with faith tend to orient their life to the goodness of others as best as they can, which in this case is organization.

Hypothesis Development. The study follows the work of Mohamad et al (2014), stating that satisfaction in Islamic perspective consists of four dimensions. They are spiritual, knowledge, social, and reward dimensions. The present study attempts to put those dimensions as constructs forming Islamic satisfaction in formative way, and determines their effects on Islamic satisfaction in Sharia banking context especially in Lahat region. It makes proxies for the four constructs; those are Islamic culture for spiritual dimension, knowledge 
sharing for knowledge dimension, subjective norms for social dimension, and reward for material dimension.

Spiritual dimension is about certain values adhered by given individuals to give meaning to life, direction to their way of life, and soul enrichment. When it comes to values, culture comes to the surface. According to Soedjono (2005), organizational culture is the values that flourish in an organization, where these values are used to direct the behavior of organization's members. Therefore its research the values used is Islamic values.

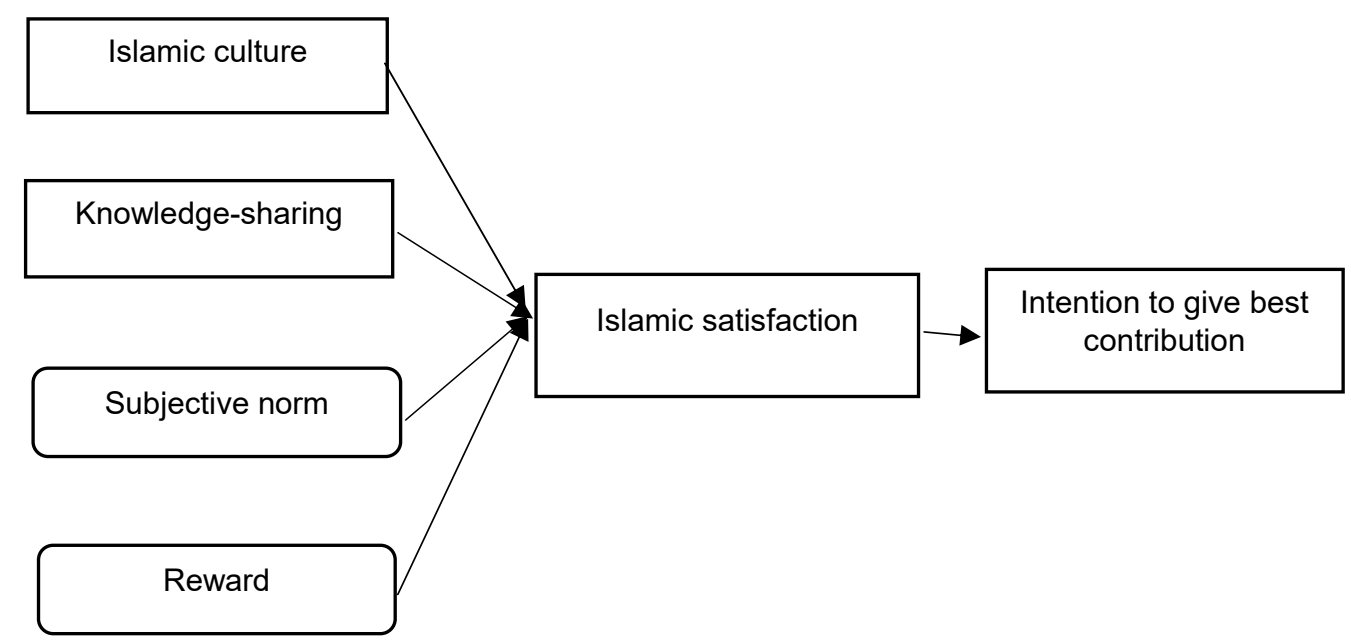

Figure 1 - Research Model

Value itself directs behavior and satisfaction in daily life (Kusaili and Kasyful, 2007). Several works have identified relationship between culture and satisfaction. Those include Purnama (2017), Park and Kim (2009), Yildirim et al (2017), Eskildsenet al (2010), Kianto et al (2016), and Chen et al (2013) support the relationship. Accordingly, this study puts forward the following hypothesis:

$\mathrm{H} 1$ : Islamic culture has a significant effect on Islamic satisfaction.

Employee can be pleasant or in positive state as a result of the fulfillment of the expectations and needs of employees for knowledge through the availability of a learning. Human is the main source of knowledge. Jiang and Hu (2016) cited research confirming that knowledge and information sharing can support competitive advantages at the organizational level (Cabrera and Cabrera 2005).At the individual level, they cite research revealing that knowledge enables for strengthened human resources (van den Hooff and van Weenen2004; Wang and Noe 2010), meets social needs (Wasko and Faraj 2000, 2005), and sustains interpersonal relationships (Bossonet al, 2006).

We argue that knowledge sharing influences life satisfaction because it fosters better relationships with one's colleagues, which in turn affect individuals' life satisfaction. Social exchange theory (Blau 1964) suggests that individuals make comparison between perceived benefits and costs when making action decisions, and expect positive feedback (Wang and Noe 2010). It is based on the norm of reciprocity, that in social exchanges, they follow mutual reciprocity pattern. It fosters social relationships in the workplace (Cropanzano and Mitchell 2005; Schoorman et al. 2007). Chiu et al. (2006) held that knowledge sharing occurs within social exchange logics. The received knowledge would induce receiving individuals to contribute knowledge. Several works have shown relationship between knowledge-sharing and satisfaction. They include Kianto et al (2016), Chen et al (2013), and Jiang and Hu (2016). Thus, the study hypothesizes:

$\mathrm{H}$ 2: Knowledge-sharing has a significant effect on Islamic Satisfaction.

Relationship between subjective norm and Islamic satisfaction has so far not been fully explored. People are generally influenced by their environment. Their work motivation are mostly guided by their world-view, values, principles, and particularly belief and faith. It is 
strengthened when institution and people inside it provide the support. When one's belief or faith is in accordance with institution encourages, then it is assumed that it would lead to satisfaction.

Subjective norms refer to people whom an individual considers important and whose ideas, values or perspectives affect his/her attitude and behavior. When their identity-related values are similar to him or her, then emerges what is usually congruence. Byrne (1971) argued that congruence with people considered important (significant others) would make individuals have more positive attitude. The congruence encourages agreement as to the important behaviors in the workplace (Schein, 1985). According to Adkins et al. (1996), this congruence would reduce tension in workplace, thus might increase satisfaction. Vancouver and Scmitt (1991) supported the relationship between congruence and satisfaction. This, this research makes the following hypothesis

H3: Subjective norm has a significant effect on Islamic satisfaction.

Rewards have so far been associated with satisfaction. Rarely researches do find insignificant relationship between rewards and satisfaction. Both extrinsic (pay and bonus) and intrinsic types (recognition and appreciation) of rewards have been considered to have effects on satisfaction. Several works have supported this such as Smith et al. (2015), Sarwar and Abugre (2013), and Ozutku (2012).

However, Islamic teachings emphasize several values that are more importantly considered than extrinsic and intrinsic rewards. For one, Islam considers the importance of basic intention or purpose of working not merely as the way of fulfilling worldly needs but also as part of worship practice to God. It means that return from the God is put first before material return from organization. Another, Islam also stresses oncharacters such as sincerity, patience, and gratefulness. Sincerity refers to motivation of doing something or giving benefits to other with the absence of personal interests. Patience refers to endurance in facing or doing things felt as encumbrance. Thus, it hypothesizes that:

$\mathrm{H} 4$ : Rewards do not have a significant effect on Islamic satisfaction.

Satisfaction is the way to achieve behavioral intention. Several works have shown the results that support relationship between satisfaction and behavioral intention. Mohamed et al., (2014) showed that satisfaction with online shopping has a significant effect on intention to continue; Rahman et al. (2017) proved that Edu-tourist's satisfaction led to intention to purchase, Ryuet al. (2010) showed the same thing in hospital context, and Wu et al. (2016) in green context.

In Islamic organization context, individuals are conceived to derive their Islamic satisfaction to their organizational indebtedness. By applying Islamic teaching regarding the importance of Shodaqoh, they might express this by attempting to give contribution to organization in order to maintain and drive its development. The contribution can be in the form of knowledge, discipline, ideas, OCB or others. Thus, the research makes a following proposition:

P1: Islamic satisfaction has a significant effect on Islamic contribution intention.

\section{LITERATURE REVIEW}

Definition of Shodaqoh. The Prophet of Muhammad has said that people should not be constrained by what they have to make shodaqoh. Life provides unlimited chances for people to make shodaqoh starting from smiling, reassuring talks, removing stones from the street through which many other people would pass by, to helping people, fulfilling family's needs, spreading religion's teachings or preventing others from making sins. By means of shodaqoh, Rosulullah call on people to make use of all activities for praying intention. Its role is instrumental, as perception that only wealthy people can make shodaqoh is replaced by the sense of fairness where all people have an equal chance to do the same thing. It is not surprising as many verses in Quran revealing considerable rewards for those who are willing to make material-related shodaqohs. Later, Rosululloh emphasizes immaterial shodaqohs that are equally important. 
It was brought up by his followers who were upset of being not able to make shodaqoh as his more fortunate followers were. It was due either to the fact that they left their belongings in Mecca, and or the financial conditions. The Prophet of Muhammad gave them reassuring reply that the chance to make shodaqoh is not limited by the amount of possessed materials. From this, it is inferred that the definition shodaqoh is highly broad, covering all deeds for the goodness of others outside oneself altruistically as part of praying to the God. In institution terms, it might refer to people's way of working that are trying their best to give optimal contributions to the advance of the institution without thinking of feedback rewards as they 'perform this altruistically as part of praying to the God. In this study, it is coined as Islamic contribution.

Meeting point of social identity, social exchange, satisfaction and planned behavior theory. Grounded on social identity theory, employees tend to internalize organization's value and identity perceived as being attractive into their own self-concept so that there is identity overlap between employees and organization. It relates to individual desire for social category. Individuals seek to define themselves in terms of social categories. Social identity serves as a means for social category that set the group where an individual decides to affiliate with apart from other groups. Organizations offer powerful identities as a source of self-categorization for individuals. The internalization of organization's identity by their employees is made possible by existing similarity between the two. Social identity need (Ashforth and Mael, 1989) makes individual has preferences for similarity in organizations. Thus, it is assured that there is a strong correlation between congruence (self-incongruity theory) and social identity.

Preference for similarity explains any effort every individual made to make adjustment, correspondence, fit, or suitability to his/her environment. If it is already achieved, each individual would seek to maintain and optimize it. The extent of fit would determine work attitudes and behaviors. Individual's decision to make adjustment is affected by perceived attractiveness in organization's value and identity. This perceived attractiveness by process of inclusion is expected to give positive paint to self-concept. The two run in synergic manner, develop and deplete together simultaneously. As Dutton et al. (1994) higher identity congruence leads to higher attraction to organizational identity.

Social exchange theory (SET) conceives the willingness of individuals to make relationships with others based on benefits and costs (Thibaut and Kelley 1959). Employees who feel to have shared identity with co-workers and or organization would have a greater chance of entering into exchange relationship. They will receive and provide much more support to each other (Van Dick and Haslam, 2012). The shared identity is the source for solidity. People perceive group boundaries when they share common interests that make them willing to share expertise, knowledge and skill with other members of a social identity (von Krogh, 2002). The existence of a shared sense of identity in a group helps group members hold shared norms, and shared values for collective action (von Krogh, 2002). Holding shared norms and shared values based on shared sense of identity is called identification and is in internalization in social identity theory and is the ground for exchange relationship.

Organization may fulfill employees' needs for belongingness, affiliation, and recognition, which provide the sense of membership. This fulfillment would drive them to develop a stronger commitment the organization for return. Synergic pattern runs in mutual simultaneous way between capability to fulfill affiliation or belongingness needs and strong commitment. The fulfillment should be social identity perceived attractive for having similar attributes to individual' self-concept. Perceived attraction is derived from expectation of its potential for being means of self-extension. From this interaction, it is obvious that there is relationship between congruence in value, identity or goal and exchange.

Deutsch (1973) argued that congruence might lead to cooperation among parties involved. In the context of goal, he thought congruence drives individuals and organization in cooperative mutual relationship. Bell (1978) found that congruence in feelings or emotions might stimulate the development of relationship among different individuals. Locke and Horowitz (1990) emphasized the effect of similarity in emotions on satisfactory interpersonal 
relationship. Yu and Chu (2007) highlighted this similarity on increased LMX (leader-member exchange). This kind of relationship falls under cost-benefit type which is the main characteristic of social exchange theory.

Satisfaction is based on expectation- confirmation theory. It was proposed by Oliver (1977) to explain satisfaction as a function of expectations, perceived performance, and confirmation of beliefs. In terms of congruence, individuals might have expectation of social identity with resulting identity or image congruence, compatibility or fit with environment with the same resulting congruence, and increased performance as the result of congruence measures.

Research has shown the positive effects of value congruence on individual attitudes such as satisfaction (Chatman, 1991; O'Reilly et al., 1991; Bretz and Judge, 1994), and satisfaction with leaders (Meglinoet al., 1991). Identity and or image congruence will sustain emotional feeling, encourage social relationship, and make easy work team. This congruence makes little or significant any conflict or other differences. It is so important to sacrifice when the conflict or difference ever surfaces. Thus, congruence in workplace enables for satisfaction.

Employees always seek compatibility to their work environment, with the effect of intentions, including intention to leave, stay, commit, and contribute. Compatibility relates to congruence. Higher congruence is more related to work attitude than lower congruence. In terms of goal congruence, several works have shown relationships between congruence and job satisfaction and turnover intention (Lovelace and Rosen, 1996; Sims and Kroeck, 1994).

Behavioral intention is derived from planned behavior theory. It is posited that behavioral intention is determined by three factors. They are attitude toward the behavior, subjective norm and perceived behavioral control (Ajzen, 2006). Attitudes refer to how positive or negative an individual feeling toward the behavior. It is strongly affected by the belief system and perception of how importance the given behavior should be performed. Congruence has been shown as being the main source of forming attitude, either it is viewed as attraction (Marin and Maya, 2013; Lam et al, 2013), organization's ability to fulfill individuals' need for affiliation (Gonzalez and Chackraborty, 2012), or norm of response in mutual relationship that engenders employees' positive attitude (Arnett et al., 2003).

Regarding to subjective norms, congruence in value and thus identity which is organization-widely shared potentially becomes subjective norms. Shared empathy, shared sense of responsibility and shared identification, among others, might turn into subjective norms where it has influential guideline on which everyone should follow or where almost all superordinate persons provide exemplary others to follow. Congruence puts most individuals in convergence and becomes uniting force to the point no individual intends to diverge for the sake of harmony and solidity.

Regarding perceived control, congruence makes possible of mutual support from coworkers and organization. Organization-wide support would enable individuals to have intention to perform a behavior he/she perceives compatible to co-workers' and organization's values. Perceived control is related to perceived support and attempt to make compatibility or fit with environment. Perceived control is supposed to be strengthened as it increases perceived congruence and fit with organization.

\section{METHODS OF RESEARCH}

The present study designs two new constructs of perceived value deemed relevant for Islamic bank within the employees' perspectives. They result from previous interviews conducted before the research, and content validity and face validity are carried out subsequently to make sure their validity and reliability. Content validity involves expert judgment in which seven experts give their evaluation on the respective construct. The resulting constructs is further tested by referring the 40 respondents' opinions of their properness. It applies saturating sampling (Sauders et al, 2009) that covers all employees and employers at Islamic banks in Lahat. 


\section{RESULTS AND DISCUSSION}

The research conceives that Islamic culture has a significant effect on Islamic satisfaction. Values developing in a wide-organization scale might coincide with employees', and it might serve a sticking attraction that strengthens their commitment and intention to stay. The so-called value congruence between employees' and organization's might be among strongest coefficient values. By this congruence, employees might find comfort with their surroundings, support to what they believe in, certainty to the right behavior, decreased conflict with other, from which personal growth and career paths might be ascertained. Values are the main pillar forming identity (Birgittaet al., 2014). In a identity-based institutions like Islamic banks, culture related to religious identity is strongly upheld.

Knowledge-sharing is also conceived to have a significant effect on Islamic satisfaction. Knowledge is important for employees to familiarize with the Islamic ways in transactions. Innovation is an issue Islamic institutions commonly face. On one hand, they should follow Islamic strict rules in transactions; however on other hand they must make innovation to compete with conventional banks that have already dominated the banking sector. The common result is that, among others, many consumers find difficulties to differentiate between Islamic and conventional practices in Islamic banks, as they are still required to pay administrative fees that can be categorized as interest payment in conventional bank. More than often they also apply conventional banks' innovation with some modification. They generally only some Islamic rules, while leaving others for feasibility reasons. Real Islamic innovations are imperative as they might reflect and foster religion belief and identity.

Subjective norms are seen to have a significant effect on Islamic satisfaction. Not many researches has explored this relation, and this might fill the gap in management literature. Subjective norms might provide pressure to individuals with incompatible values, ideas or perspective to make some adjustments. The pressure would turn into agreement, support, and understanding that allow for increased cohesiveness, esteem, and satisfaction in the workplace. This is in line with the work of Schein (1985) and Vancouver and Smitt (1991). Arguably, Islamic banks have a better leverage than conventional banks in terms of identityrelated value congruence. So, it should be no surprise to see that some conventional banks, domestic and international, apply Islamic procedures. Another effect is that not all banks with Islamic procedures (Shariah) offer identity-related value congruence since some conventional banks also offer Syariah services. Somehow, employees develop value perception from organization's common practices or procedures. When the practices or procedures relate to religion teachings, the resulting value perception might lead to identity perception.

Rewards as the old concept do not suffice to warrant Islamic satisfaction. The old concept that sees rewards as being composed of intrinsic and extrinsic would not fully represent Islamic expectation. Though some Islamic individuals still think that these kinds of rewards important for their life, many others have expectations that might overshadow those rewards. Individual Moslems may be driven to make some virtues without expecting rewards. Some studies have argued that similarity induces empathy. Identity congruence and support between organization and consumers or employees tends to make the latter into more feel empathy. As long as organization is able to put forward identity or values suitable to ones' selves, they are agued, emotional feelings can be induced to turn into empathy (Preston and de Waal, 2002; Barnett.

Thus, beside extrinsic and intrinsic types of rewards, there are another ways to attract and maintain employees such as identity attractiveness and self-extension. Both converges on similarity that provides attraction and chance for employee to represent themselves through organization's identity. Bhattacharya and Sen (2003) have made relationship between identity attractiveness and similarity, beside distinctiveness and prestige.

Islamic satisfaction is conceived to be significantly related to Islamic contribution intention. Islamic satisfaction is derived from organization capability to fulfill stakeholders' expectations, while intention to give best intention is directed to the organization. Explaining the significant relationship between the two involves intersection of social exchange, social 
identity, and expectation-confirmation theories. Identity might relate to exchange within the framework that as long as individuals' needs of identity are fulfilled they would be likely to do something to foster relation to or do something to show gratitude to organization for doing so. It could be in the form of identification (where individuals consider an organization's identity as theirs), expansion (individuals take in organization's identity into themselves) or support the development of the organization for the purpose of its maintenance as extension of their identity.

Further researches are still important to explore more deeply relationship between rewards and Islamic satisfaction. For example, it might be highly useful to develop new constructs such as Islamic rewards, balanced rewards based on both seniority and merit, or others in the relationship to Islamic satisfaction. Otherwise, insertion of another variable in the relationship between rewards and Islamic satisfaction to make it into positively significant would be instrumental.

If the same model to be maintained, new relationships also worth developing. That is, relationships could be made between Islamic culture and Islamic contribution intention, knowledge-sharing and Islamic contribution intention, subjective norm and Islamic intention contribution intention, and between rewards and Islamic contribution intention that make Islamic satisfaction turn into mediator. It also could be applied to Islamic banks in different contexts for comparison purposes, such as Islamic banks from domestic and foreign countries.

Future research also can include other variable other than knowledge sharing for knowledge dimension of Islamic satisfaction. Other dimension of knowledge might beconsidered important and have important effects on Islamic satisfaction. Exploration of other dimensions of knowledge might contribute to knowledge of Islamic satisfaction.

Moderating variables worth considering as it might increase chance for a more complete picture of variables operating to lead to Islamic contribution intention. For the same purpose, exploration also could be made between variables that form Islamic satisfaction. As it would provide a deeper knowledge to managers which variables affecting Islamic satisfaction that merit special attention to increase employees' satisfaction.

\section{CONCLUSION}

All relationships predicted in this study are conceived to be positively significant, except that between rewards and Islamic satisfaction. It might imply that the concept of rewards is not suitable to the Islamic teachings, and some changes would allow for suitability. It might due to the fact that In Islamic teaching there is emphasis on giving without asking return (Ikhlas) and purposes intended only to the God that makes material and immaterial rewards lose their attractiveness.

More interesting is a significant and positive relationship between Islamic satisfaction and Islamic contribution intention. Instead of its novelty, it deserves replicating in other contexts such business firms or conventional banks with the framework of value congruence theories. Islamic notion might hinder generalization, but it can be handled by inserting equally philosophical terms in front of satisfaction and intention variables.

Identity congruence can be applied for planned behavior context. This study proves that identity congruence can clarify the assumed phenomenon in planned behavioral context of Islamic banks, serving as a meeting point between social identity, social exchange and expectation-confirmation theories.

\section{REFERENCES}

1. Adkins, C.A , Elizabeth, C.R., Meglino, B., M. 1996. Value congruence between coworkers and its relationship to work outcomes. Group \& Organization Management .21, 4. P. 439 
2. Al-Ghazali, Imam Abu Hamid Muhamed Bin Muhammad. 1976. Kimya'usSaadah(Kimia Kebahagiaan). Transl. Abdul Majid Bin Hj. Khatib. PustakaAman Press Sdn. Bhd. Kota Bharu, with cooperation with Kelantan SH. Muhammad Ashraf, Lahore Pakistan.

3. Ashforth, B.E. and Mael, F.A. 1989. Social identity theory and the organization.Academy of Management Review, Vol. 14 No. 1, pp. 20-39.

4. Ajzen, I. 2006. The theory of planned behavior. Retrieved January, 09, 2011 from: http://people.umass.edu/aizen/tpb.html.

5. Bhattacharya CB, Sen S. 2003. Consumer-company identification: a framework for understanding consumers' relationships with companies. J Mark 67(2):76-88. doi:10.1509/jmkg.67.2.76.18609

6. Bell, P.A. 1978. Affective state, attraction, and affiliation: misery loves happy company, too. Personality and Social Psychology Bulletin, Vol. 4 No. 4, pp. 616-619.

7. Blau, P. M. 1964. Exchange and power in social life. New Brunswick, NJ: Transaction Publishers

8. Bosson, J. K., Johnson, A. B., Niederhoffer, K., \& Swann, W. B. (2006). Interpersonal chemistry through negativity: Bonding by sharing negative attitudes about others.Personal Relationships, 13(2), 135-150.

9. Bretz, R.D. and Judge, T.A. 1994. Person-organization fit and theory of work adjustment: implications for satisfaction, tenure, and career success. Journal of Vocational Behavior, Vol. 44 No. 1, pp. 32-54.

10. Chatman, J.A. 1991. Matching people and organizations: selection and socialization in public accounting firms. Administrative Science Quarterly, Vol. 36 No. 3, pp. 459-484.

11. Cabrera, E. F., and Cabrera, A. 2005. Fostering knowledge sharing through people management practices. The International Journal of Human Resource Management, 16(5), 720-735.

12. Chen, Z.S.C., Yang, S.J.H., and Huang, J.S. H. 2013. Constructing an e-Portfolio-Based Integrated Learning Environment Supported by Library Resource. The Electronic Library, Vol. 33, No. 2, pp. 273-291.

13. Chiu, C.-M., Hsu, M.-H., \& Wang, E. T. 2006. Understanding knowledge sharing in virtual communities: An integration of social capital and social cognitive theories. Decision Support Systems, 42(3), 1872-1888.

14. Cropanzano, R., \& Mitchell, M. S. 2005. Social exchange theory: An interdisciplinary review. Journal of Management, 31(6), 874-900.

15. Deutsch, M., 1973. The Resolution of Conflict. New Haven, CT: Yale University Press.

16. Din, H., Salleh, H., and Yasin, S.1989. Manusiadan Islam. (Edisi Kelima). Selangor: Hizbi Marketing Sdn. Bhd.

17. Dutton, J.E., Dukerich, J.M. and Harquail, C.V. 1994. Organizational images and memberldentification. Administrative Science Quarterly, Vol. 39 No. 2, pp. 239-263

18. Eskildsen, J., Kristensen, K., and Antvor, H. 2010. The Relationship between Job Satisfaction and National Culture. Asian Economic and Financial Review. Asian Economic and Financial Review, Vol. 7, No. 5, pp. 528-540.

19. Gonzales, J.A., and Chakraborty, S. 2012. Image and similarity: an identity orientation perspective to organizational identification. Leadership \& Organization Development JournalVol. 33. No. 1, pp. 51-65.

20. Haron Din, Hassan Salleh, SulaimanYasin .1989. Manusiadan Islam. (EdisiKelima). Selangor: Hizbi Marketing. Sdn. Bhd.

21. Hayaati. 2010. Etika Penjawat Awamdari Perspektif Islam. Kuala Lumpur: Dewan Bahasa dan Pustaka.

22. Jiang, Z., and Hu, X. 2016. Knowledge-Sharing and Life Satisfaction: The Roles of Colleague Relationships and Gender. Soc. Indic. Rec. 126, pp. 379-394.

23. Kianto, A., Vanhala, M., and Heilmann, P. 2016. The impact of Knowledge Management on Job Satisfaction. Journal of Knowledge Management, Vol. 20, No., 4.

24. Kusaili, A. and A. Kasyful, 2007. Analisis pengaruh komitmen organisasi dan keterlibatan kerja terhadap hubungan antara Etika kerja Islam dengan sikap perubahan organisasi. Jurnal Ekonomi Pembangunan, Manajemen dan Akuntansi, 6(3): 265 - 278. 
25. Lam, S.K., Ahearne, M., Mullins, R., Hayati, B., Schillewaert, N. 2013. Exploring the dynamics of antecedents to consumer-brand identification with a new brand. J. of the acad. Mark.Sci.41: 234-252

26. Locke, K.D. and Horowitz, L.M. 1990. Satisfaction in interpersonal interactions as a function ofsimilarity in level of dysphoria. Journal of Personality and Social Psychology, Vol. 58 No. 5, pp. 823-831

27. Lovelace, K., \& Rosen, B. 1996. Differences in achieving person-organization fit among diverse groups of managers. Journal of Management, 22, 703-723

28. Meglino,B.M.,Ravlin, E.C. and Adkins, S.L. 1991. Value congruence and satisfaction with a leader: an examination of the role of interaction. Human Relations, Vol. 44 No. 5, pp. 481-495.

29. Mohamad, B., Saadiah, H., Saad, M., and Ismail, S.H. S. 2014. The Role of Integrity as a Mediator between Work Satisfaction and Work Performance in the Perspective of Islam: An Empirical Approach Using SEM/AMOS Model. International Journal of Research in Applied, Natural and Social Sciences (IMPACT: IJRANSS), Vol. 2, issue 1, pp. 71-84.

30. Mohamed, N., Hussein, R., Hidayah, N., Zamzuri, A., and Haghshenas, H. 2014. Insights into individual's online shopping continuance intention. Industrial Management \& Data Systems. Vol. 114, No. 9, pp. 1453-1476

31. O'Reilly, C.A. III, Chatman, J. and Caldwell, D.F. 1991. People and organizational culture: a profile comparison approach to assessing person-organization fit. Academy of Management Journal, Vol. 34 No. 3, pp. 487-516.

32. Ozutku, H. 2012. The influence of intrinsic and extrinsic rewards on employee results: an empirical analysis in Turkish Manufacturing Industry. Business and Economics Research Journal. Vol. 3.

33. Park, J.S., and Kim, T.H. 2009. Cultural matterin nurse job satisfaction and turnover intention. Leadership in Health Services, Vol. 22, No. 1, pp. 20-38.

34. Purnama, S. 2017. Islamic Culture Impacts of Increasing Satisfaction and Performance of Employees: Study of Educational Institutions Sabillilah Sampang. Asian Economic and Financial Review, 7 (5): 528-540.

35. Rachman, M.S., Hassan, H, Osman-Gani, Fattah, F., A., M., A., and Anwar, M.A. 2017. Edu-tourist's perceived service quality and perception - the mediating role of satisfaction from foreign students' perspectives. Tourism Review. Vol. 72, No. 2.

36. Ryu, K., Han, H., and Jang, S.. 2010. Synthesizing the effects of green experiential quality, green quality, green equity, green image and green experiential satisfaction on green switching intention. Vol. 22, No. 3, pp. 416-432.

37. Saadiah. 2008. Kepuasan Kerja Menurut Perspektif Islam: Kajian di Pejabat Daerah Ranau, Sabah. Tesis Sarjana. Bahagian Pengajian Syariah, Jabatan Siasah Syariyyah, Akademi Pengajian Islam,Universiti Malaya, Kuala Lumpur.

38. Sarwar, S., and Abugree, J. 2013. The influence of rewards and job satisfaction on employees in the service industry. The Business \& Management Review, Vol. 3, No. 2.

39. Saunders, M,. Lewis, P., Tornhill. A. 2009. Research Method For Business Students, Pearson Education, London

40. Schein, E.H. 1985. Organizational culture and leadership. San Fransisco: Jossey Bass.

41. Smith, E., Jouberth, P., and Karoia, A.M. 2015. The impact of intrinsic and extrinsic rewardson employee motivation at a medical devices company in South Africa. Kuwait Chapter of Arabian Journal of Business and Management Review. Vol. 5, No.1.

42. Schoorman, F. D., Mayer, R. C., and Davis, J. H. 2007. An integrative model of organizational trust: Past, present, and future. Academy of Management Review, 32(2), 344-354

43. Sims, R. L., \&Kroeck, K. G. 1994. The influence of ethical fit on employee satisfaction, commitment and turnover. Journal of Business Ethics, 13, 939-948

44. Soedjono, 2005. Pengaruh Budaya Organisasi Terhadap Kinerja Organisasi dan Kepuasan Kerja Karyawan pada Terminal Penumpang Umum di Surabaya. Jurnal Manajemen dan Kewirausahaan, 7(1): 22-47.

45. Thibaut, J. W., \& Kelley, H. H. 1959. The social psychology of groups. New York: Wiley. 
46. Yildirim, S., Acaray, A., and Aydin, K. 2017. Exploring the impact of marketing culture on job satisfaction. Woeld Journal of Entrepreneurship, Management and Sustainable Development. Vol., 13, No. 2, pp. 151-162.

47. Yu, C.P. and Chu, T.H. 2007. Exploring knowledge contribution from an OCB perspective. Information \& Management, Vol. 44 No. 3, pp. 321-331.

48. Vancouver, J.B. and Smitt, N.W. 1991. An exploratory examination of fit-organization fit: organizational goal congruence. Personnel Psychology, 44, 333-352.

49. Van den Hooff, B., and de Leeuw van Weenen, F. 2004. Committed to share: Commitment and $\mathrm{cmc}$ use as antecedents of knowledge sharing. Knowledge and Process Management, 11(1), 13-24.

50. VanDick, R. and Haslam, S.A. 2012. Stress and well-being in the workplace: support for key propositions from the social identity approach, in Jetten, J., Haslam, C. and Haslam, S.A. (Eds), The Social Cure: Identity Health, and Well-being, Psychology Press, Hove and New York, NY, pp. 175-194.

51. Von Krogh, G. 2002. The communal resource and information systems. Journal of Strategic Information Systems, 11(2), 85-107.

52. Wang, S., andNoe, R. A. 2010. Knowledge sharing: A review and directions for future research. Human Resource Management Review, 20(2), 115-131.

53. Wasko, M. M., \& Faraj, S. 2000. "It is what one does": Why people participate and help others in electronic communities of practice. The Journal of Strategic Information Systems, 9(2), 155-173.

54. Westover, J.H. \& Taylor, J. 2010. International differences in job satisfaction: The effects of public service motivation, rewards and work relations. International Journal of Productivity and Performance Management, Vol. 59 Iss: 8 pp. $811-828$.

55. $\mathrm{Wu}, \mathrm{H}-\mathrm{C}$. Ai, Ai, C-H., Cheng, C-C. 2017. Syntesizing the effects of green experiential quality, green equity, green image and green experiential satisfaction on green switching intention. International Journal of Contemporary Hospitality Management, Vol. 28. N0. 9. Pp. 2080-2107. 